\title{
Motivation, Physical Work Environment, Non- Physical Work Environment, and Work Satisfaction (Study on the Government of Ternate City)
}

\author{
Muhammad Asril Arilaha ${ }^{1, *}$, Johan Fahri ${ }^{1}$, Nurlela ${ }^{1}$, \\ Abdullah W. Jabid ${ }^{1}$, Irfandi Buamonabot ${ }^{2, *}$ \\ ${ }^{1}$ Department of Management, Faculty of Economics and Business, Khairun University, Ternate, Indonesia \\ ${ }^{2}$ Polteknik Sains \& Teknologi Wiratama Maluku Utara, Ternate, Indonesia \\ *Corresponding author.Email: asril_arilaha@unkhair.ac.id
}

\begin{abstract}
This study aims to examine the effect of motivation, physical work environment, non-physical work environment and job satisfaction on performance. A total of 63 respondents from Non-permanent Employees in the Regional Government of Ternate were surveyed in this study. The analytical tool used in this study is regression analysis. The results showed that of the four hypotheses proposed in this study, only hypothesis 1 was unsupported. Furthermore, at the end of the research results are discussed in this study.
\end{abstract}

Keywords: motivation, physical work environment, non-physical, job satisfaction, performance

\section{INTRODUCTION}

The growth and development of an organization depend on human resources. Therefore, human resources is an asset that should be improved effectively and efficiently in order to materialize its optimal performance. To achieve this, the organization, in this case, must be able to create a situation that can encourage employees to develop abilities and skills optimally, especially in terms of performance. Whether or not performance depends greatly on the extent to which the agency is able to design the form of motivation provided to its employees. This certainly must be supported by an adequate work environment [1].

Motivation is one of the variables that affect performance [2-4]. This is due to high motivation that will be able to improve employee performance. There is two motivations namely extrinsic and intrinsic motivation. Every employee has desires and goals to be achieved in work, so high motivation is needed to improve good performance [5]. In addition to motivation, the work environment is also a factor influencing performance [6,7]. The work environment itself consists of the physical environment and non-physical environment attached to employees so that it cannot be separated from the performance development effort [8]. Work environments such as work atmosphere, relationships with colleagues, availability of work facilities, noise and odor will contribute to the comfort of employees in performing their duties [9].

This study is a replication of several previous studies. The study was based on the findings were inconsistent. For example, [10-12] find that motivation has no effect on performance, while [2-4] found that motivation influences performance. Furthermore, research conducted by $[1,13]$ also found insignificant results on the effect of working environment on performance, while $[6,7,14]$ found that the work environment influences performance. In addition to reexamining the results of research that have not been consistent, researchers also added two variables, namely job satisfaction and dividing the work environment based on physical and non-physical, so researchers want to test each variable on performance

\section{METHODS}

Research design

The design of this research is a descriptive study with a survey method. Data collection in this study was carried out by a cross-sectional method that is collecting or retrieving data at a certain time (Neuman, 2006).

\section{Population and Sample}

The population in this study were all employees of the Department of Education and Culture of Ternate City. The sample in this study was 63 non-permanent employees at the Department of Education and Culture of Ternate City. A sample size of more than 30 and less than 500 is appropriate for most studies [15].

\section{Test Validity and Reliability}

Validity is the level at which a test measures what it really wants to be measured. Validity testing is done by factor analysis to get construct validity. The items used in this study are those that have a factor loading value $\geq 0.5$ [16]. Reliability is related to the accuracy and precision of a measurement procedure [17]. In this study, reliability testing is done by looking at the value of Cronbach's Alpha 
is in the top 0.7 [16]

Hypothesis testing

Hypothesis testing 1, 2, 3 and 4 was performed using regression analysis [16].

\section{Research Instruments}

Work motivation, physical and non-physical environment and performance variables are measured using questions developed by [18], with the number of each question for each variable being 11, 8, 4 and 10 question items using a Likert scale with 1 not very agree up to 5 strongly agree. For job satisfaction variables measured by using 5 item statements developed by [19], which use a Likert scale with 1 strongly disagreeing to 5 strongly agreeing

\section{RESULTS AND DISCUSSION}

Based on the results of the distribution of the questionnaires in table 1 , then of $77(77 \%)$ returned questionnaires, only $63(63 \%)$ of the questionnaires were declared eligible for analysis in order to test the hypothesis. Thus the response rate in the study was $63 \%$ (see table 1). Of the total 63 respondents, only 42 were male and the remaining 21 were female with the majority already married, as many as 45 people and the rest were not married (see table 2).

Table 1 Results of Questionnaire Distribution

\begin{tabular}{|l|c|c|}
\hline \multicolumn{1}{|c|}{ Information } & Total & Percentage \\
\hline $\begin{array}{l}\text { Distributed } \\
\text { Questionnaires }\end{array}$ & 100 & $100 \%$ \\
\hline Returned questionnaires & 77 & $77 \%$ \\
\hline $\begin{array}{l}\text { Processed } \\
\text { Questionnaire }\end{array}$ & 63 & $63 \%$ \\
\hline
\end{tabular}

Source: Processed Data

Descriptive statistics are intended to recognize data patterns and summarize the information contained in data. This study presents the mean and standard deviation. Based on the results of data processing in table 3 the standard deviation value is not greater than 0.4. This means that the smaller the deviation standard means of data clustered around the average value and do not show a high variation, and vice versa [20].

Table 2. Resepondent Charactertics

\begin{tabular}{|l|c|c|}
\hline \multicolumn{1}{|c|}{ Charaterisitics } & Total & Percentage \\
\hline Gender & & \\
\hline Male & 42 & $67 \%$ \\
\hline Female & 21 & $33 \%$ \\
\hline Marital Status & & \\
\hline Married & 45 & $71 \%$ \\
\hline Single Belum Menikah & 18 & $29 \%$ \\
\hline
\end{tabular}

Source: Processed Data
Furthermore, based on the results of data processing, the average value only works motivation which has the lowest value of 3.42 and is in the sufficient category for the variable of work motivation and the performance variable with the highest value of 4.20 and is at a high level.

Table 3. Descriptive Statistics

\begin{tabular}{|l|c|c|}
\hline \multicolumn{1}{|c|}{ Variable } & Mean & $\begin{array}{c}\text { Standard } \\
\text { Deviation }\end{array}$ \\
\hline Work motivation & 3.42 & 0.83 \\
\hline Physical Work Environment & 4.05 & 0.23 \\
\hline $\begin{array}{l}\text { Non-Physical Work } \\
\text { Environment }\end{array}$ & 4.07 & 0.23 \\
\hline Job satisfaction & 4.03 & 0.27 \\
\hline The performance & 4.20 & 0.28 \\
\hline
\end{tabular}

Source: processed data

The results of validity testing show that the variables of work motivation, physical work environment, nonphysical work environment, job satisfaction, and performance have a KMO Measures of Sampling Adequacy value and factor loading above 0.5. Likewise with the results of the reliability testing showed that for all variables in this study had a Cronbach's Alpha value above 0.7 , so that overall the research variables were declared valid and reliable.

Hypothesis 1 states that there is a positive influence on work motivation on performance. Based on the results of the regression analysis showed that work motivation did not have a significant effect $(\beta=0.010, \mathrm{t}=0.482, \mathrm{P}$ $<0.05)$. This means that hypothesis 1 is not supported. This is because the motivation perceived by respondents is generally at a low level, such as salary and the absence of old age savings. In addition, the results of this study are not in accordance with previous studies [2-4]. This is more based on the respondents used in each study. The results of this study also support the results of research [10-12], that motivation does not affect performance.

Hypothesis 2 states that there is a positive influence on the physical work environment on performance. The results of the regression analysis showed that the physical work environment had a significant positive effect $(\beta=0,661, \mathrm{t}$ $=5,198, \mathrm{P}<0.05)$. This means hypothesis $\mathbf{2}$ is supported. Hypothesis 3 states that there is a positive influence of the non-physical work environment on performance. Regression analysis showed that non-physical work environment had a significant positive effect $(\beta=0.331$, $\mathrm{t}$ $=2.688, \mathrm{P}<0.05)$. This means hypothesis 3 is supported. The results of this study are in accordance with the opinion of [21] that the physical work environment such as work facilities, lighting, air circulation, noise, odor and comfort and non-physical as well as working atmosphere and relationships with well - managed colleagues will have an impact on high performance. These results are also in accordance with research $[6,7,14]$. 
Table 4. Validity dan Reliability Tests

\begin{tabular}{|c|c|c|c|c|}
\hline \multirow[b]{2}{*}{ Statement No. } & \multicolumn{2}{|l|}{$\begin{array}{r}\text { Validity } \\
\end{array}$} & \multirow{2}{*}{$\begin{array}{c}\text { Reliability } \\
\text { Cronbach's } \\
\text { Alpha }\end{array}$} & \multirow[b]{2}{*}{ Remark } \\
\hline & $\begin{array}{c}\text { KMO Measures of } \\
\text { Sampling Adequacy }\end{array}$ & $\begin{array}{l}\text { Component } \\
\text { Matrix }\end{array}$ & & \\
\hline MK1 & 0,677 & 0,863 & 0,941 & Valid dan Reliable \\
\hline MK2 & & 0,519 & & \\
\hline MK3 & & 0,807 & & \\
\hline MK4 & & 0,758 & & \\
\hline MK5 & & 0,844 & & \\
\hline MK6 & & 0,756 & & \\
\hline MK7 & & 0,862 & & \\
\hline MK8 & & 0,821 & & \\
\hline MK9 & & 0,761 & & \\
\hline MK10 & & 0,818 & & \\
\hline MK11 & & 0,914 & & \\
\hline LKF1 & 0,668 & 0,554 & 0,891 & Valid dan Reliable \\
\hline LKF 2 & & 0,781 & & \\
\hline LKF 3 & & 0,533 & & \\
\hline LKF 4 & & 0,599 & & \\
\hline LKF 5 & & 0,889 & & \\
\hline LKF 6 & & 0,578 & & \\
\hline LKF 7 & & 0,646 & & \\
\hline LKF 8 & & 0,829 & & \\
\hline LKF 9 & & 0,844 & & \\
\hline LKF 10 & & 0,550 & & \\
\hline LKF 11 & & 0,619 & & \\
\hline LKF 12 & & 0,773 & & \\
\hline LKNF1 & 0,775 & 0,855 & 0,741 & Valid dan Reliable \\
\hline LKNF2 & & 0,863 & & \\
\hline LKNF3 & & 0,875 & & \\
\hline LKNF4 & & 0,676 & & \\
\hline KK1 & 0,537 & 0,712 & 0,747 & Valid dan Reliable \\
\hline KK2 & & 0,640 & & \\
\hline KK3 & & 0,807 & & \\
\hline KK4 & & 0,757 & & \\
\hline KK5 & & 0,611 & & \\
\hline K1 & 0,720 & 0,801 & 0,919 & Valid dan Reliable \\
\hline $\mathrm{K} 2$ & & 0,695 & & \\
\hline K3 & & 0,703 & & \\
\hline K4 & & 0,870 & & \\
\hline K5 & & 0,696 & & \\
\hline K6 & & 0,747 & & \\
\hline K7 & & 0,798 & & \\
\hline K8 & & 0,727 & & \\
\hline K9 & & 0,748 & & \\
\hline K10 & & 0,861 & & \\
\hline
\end{tabular}

Source: Processed Data 
Table 5. Regression Analysis Results

\begin{tabular}{|l|c|c|c|c|}
\hline \multicolumn{1}{|c|}{ Variables } & $\boldsymbol{\beta}$ & Std. Error & $\mathbf{t}_{\text {count }}$ & Sig. t (P Value) \\
\hline Constant & $-0,516$ & .352 & $-1,467$ & 0.148 \\
\hline Work motivation & 0.010 & 0.021 & .482 & 0.632 \\
\hline $\begin{array}{l}\text { Physical Work } \\
\text { Environment }\end{array}$ & .661 & 0.127 & 5,198 & 0,000 \\
\hline $\begin{array}{l}\text { Non-Physical Work } \\
\text { Environment }\end{array}$ & .331 & 0.123 & 2,688 & 0.009 \\
\hline Job satisfaction & .168 & 0.073 & 2,268 & 0.027 \\
\hline Multiple R. & .879 & & & \\
\hline R Square & .773 & & & \\
\hline Adj. R Square & 0,757 & & & \\
\hline
\end{tabular}

Source: processed data

Hypothesis 4 states that there is a positive influence on job satisfaction on performance. The results of the regression analysis showed that job satisfaction had a significant positive effect $(\beta=0.168, \mathrm{t}=2.268, \mathrm{P}<0.05)$. This means hypothesis 4 is supported. The results of this study are consistent with [22] opinion that the success of an organization is highly dependent on employee participation and performance. Employees are people who are responsible for achieving the organization's vision and goals. Characteristics and positive feelings of employees towards the work they do lead to job satisfaction.

\section{CONCLUSION}

Based on the results of the research stated above, this study concludes that:

1. Of the four hypotheses proposed in this study, only one hypothesis was unsupported.

2. Related to the motivational system applied by the ternate city government to non-permanent employees, they should pay attention to the amount of salary and pension benefits to be provided.

\section{REFERENCES}

[1] Arianto, D. A. N. 2013. Pengaruh Kedisiplinan, Lingkungan Kerja dan Budaya Kerja terhadap Kinerja Tenaga Pengajar. Jurnal Economia, Volume 9, Nomor 2, Oktober 2013. Hal. 191200.

[2] Rusmawita,. 2016. Pengaruh Motivasi dan Lingkungan Kerja terhadap Kinerja Pegawai Dinas Perkebunan Kabupaten Mamuju Utara. $e$ Jurnal Katalogis, Vol. 4, No. 5. Hal. 121-127.

[3] Prihantoro, A. 2012. Peningkatan Kinerja Sumber Daya Manusia melalui Motivasi, Disiplin, Lingkungan Kerja, dan Komitmen (Studi Kasus Madrasah di Lingkungan Yayasan Salafiyah, Kajen, Margoyoso, Pati). Value Added, Vol.8, No.2, Hal. 78-98.
[4] Oktaviannand, R., Pandjaitan, N.K., \& Kuswanto, S. 2017. Effect of Job Satisfaction and Motivation towards Employee's Performance in XYZ Shipping Company, Journal of Education and Practice. Vol. 8, No. 8. pp 7279

[5] Suddin, A. and Sudarman. 2010. Pengaruh Kepemimpinan, Motivasi, dan Lingkungan Kerja terhadap Kinerja Pegawai Kecamatan Laweyan Kota Surakarta. Jurnal Manajemen Sumber Daya Manusia. Volume 4. No. 1. Juni 2010. Hal. 1-8.

[6] Potu, A. 2013. Kepemimpinan, Motivasi, dan Lingkungan Kerja Pengaruhnya terhadap Kinerja Karyawan pada Kanwil Ditjen Kekayaan Negara Suluttenggo Dan Maluku Utara Di Manado. Jurnal EMBA. Vol.1 No.4. Hal. 1208-1218.

[7] Hidayat, Z. dan Taufiq. 2012. Pengaruh Lingkungan Kerja dan Disiplin Kerja serta Motivasi Kerja Terhadap Kinerja Karyawan Perusahaan Daerah Air Minum (PDAM) Kabupaten Lumajang. Jurnal WIGA. Vol. 2 No. 1, Maret 2012. Hal. 79-97.

[8] Sedarmayanti. 2009. Tata Kerja dan Produktivitas Kerja. Bandung: Mandar Maju.

[9] Nitisemito, A.S., 2008. Manajemen Personalia, CV. Ghalia Indonesia, Jakarta.

[10] Munpriadi. 2012. Pengaruh Kepemimpinan, Motivasi, Pelatihan, dan Lingkungan Kerja terhadap Kinerja Karyawan pada Perusahaan Daerah Air Minum Tirta Musi Kota Palembang. Jurnal Orasi Bisnis. Edisi ke-VII. Hal. 47-54.

[11] Hayati, K. \& Caniago, I. 2012. Islamic work ethic: The role of intrinsic motivation, job satisfaction, organizational commitment and job performance. Procedia-Social and Behavioral Sciences, 65, 272-277.

[12] Murti, H., dan Srimulyani, V.A. 2013. Pengaruh Motivasi terhadap Kinerja Pegawai dengan Variabel Pemediasi Kepuasaan Kerja Pada PDAM Kota Madiun. Jurnal Riset Manajemen dan Akuntansi. Vol. 1. No. 1. Hal. 10-17.

[13] Al-Omari, K. \& Okasheh, H. 2017. The 
Influence of Work Environment on Job Performance: A Case Study of Engineering Company in Jordan. International Journal of Applied Engineering Research. Vol. 12. No. 24.

[14] Shintia, R. 2018. Pengaruh Lingkungan Kerja dan Kepuasan Kerja terhadap Kinerja Pegawai pada Kantor Perwakilan Bank Indonesia Medan Provinsi Sumatera Utara. Skripsi. Universitas Muhammadiyah Sumatera Utara. Medan.

[15] Roscoe, J., 1975. Fundamental Research Statistics for the Behavioral Sciences. New York: Holt, Rinehart \& Winston.

[16] Hair, J. F. Jr., William, C. B., Banin, B. J., \& Anderson, R. E. 2010. Multivariate Data Analysis. $7^{\text {th }}$ edition. Upper Saddle RiverPrentice Hall. New Jersey.

[17] Cooper, D. R., \& Schlinder. P. S. 2008. Business Research Methods, $10^{\text {th }}$ edition. Mc Graw. New York.

[18] Kusuma, A.A. 2013. Pengaruh Motivasi dan
Lingkungan Kerja terhadap Kinerja Karyawan Hotel Muria Semarang. Skripsi Universitas Negeri Semarang.

[19] Brayfield, A. H., \& Rothe, H. F. 1951. An Index of Job Satisfaction, Journal of Applied Psychology, 35: 307-311.

[20] Sekaran, Uma. 2006. Research Method for Business: A Skill-Building Approach, $3^{\text {rd }}$ Edition, John Wiley and Sons. New York.

[21] Neuman, W. L. 2006. Social Research Method: Qualitative and Quantitative Approaches. $6^{\text {th }}$ edition. New Jersey: Pearson Education, Inc.

[22] Munisamy, S. 2013. Identifying Factors That Influences Job Performance Amongst Employees In Oil Palm Plantation. A Project Paper Submitted In Partial Fulfillment Of The Requirements For The requirements for the degree of Bachelor in Psychology, Faculty of Applied Social Sciences Open University Malaysia. 